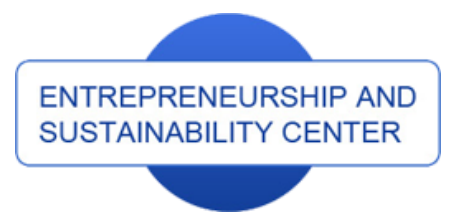

Publisher

http://jssidoi.org/esc/home enterprise

europe

network

Business Support on Your Doorstep

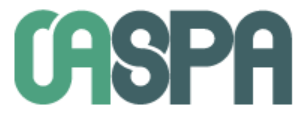

\title{
SCIENCE AND INNOVATION POLICIES IN NORTH AFRICAN COUNTRIES: EXPLORING CHALLENGES AND OPPORTUNITIES*
}

\author{
Amr Radwan \\ ${ }^{1}$ Academy of Scientific Research and Technology, 101 Kasr Al-Ainy str. 11516, Cairo, Egypt \\ E-mail:amm@sti.sci.eg
}

Received 15 April 2018; accepted 10 July 2018; published 30 September 2018.

\begin{abstract}
Effective science, technology and innovation (STI) policies and strategies reflect a country's successful contribution to scientific advancement. While the economic and geopolitical framework of many North African Countries (NACs) transformed enormously during the past decades, their relevant policies and performance were not responsive enough in adapting to these dynamics. This review is meant to highlight the current development and evolution of NAC's STI policies as well as similarities and identified common societal challenges within NACs. It focusses on the nexus approach to water, energy and food. The findings of this review suggest that the existing reform and development of the STI system in NACs require reorientation towards higher socioeconomic relevance and innovation focus accompanied by legislative measures, effective monitoring and evaluation tools as well as engagement of relevant stakeholders and the adequate leverage of sufficient strategic investments.
\end{abstract}

Keywords: Science policy; innovation ecosystem; North Africa; North African Countries; technology development

Reference to this paper Radwan, A. 2018 Science and innovation policies in North African Countries: Exploring challenges and opportunities, Enterpreneurship and Sustainability Issues 6(1): 268-282. http://doi.org/10.9770/jesi.2018.6.1(17)

JEL Classifications: O1; 031; 032; 044; 055

* This work received support from a project 5TOI_4EWAS (Energy, Water and Agriculture in the South Mediterranian Neigbourhood) co-funded by the Horizon 2020 Framework Programme of the European Union under Grant Agreement $n^{\circ}$ 692523
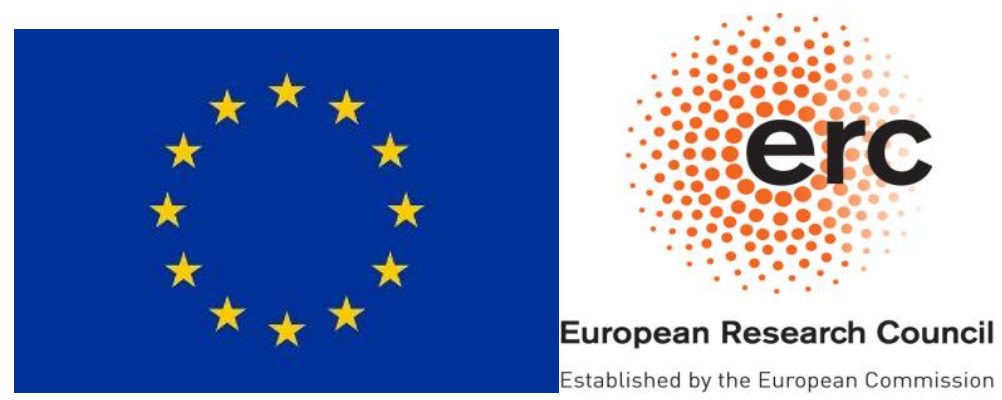


\section{Introduction}

Science and technology (S\&T) policies in North African Countries (NACs) were first developed in the 1990s. Egypt developed its S\&T framework initiative in 1994 while Jordan adopted its national S\&T policy a year later (Bizri, 2018e; Hanafi \& Arvanitis, 2015). Currently, most North African Countries have national S\&T policies and strategies. Some of these policies set very ambitious goals. For instance, Egypt aims to be among the top 40 countries worldwide in the fields of innovation, quality of scientific research institutions in addition to retention of innovative talents and capabilities by 2030 while being among the top 20 for the number of patents per year (Ayad, 2015; Bizri, 2018b).

Following 2011, several radical changes in science, technology and innovation policies have occurred in many NACs. After decades of stagnation, Egypt adopted in 2014 a new constitution which mandates the allocation of $1 \%$ Gross Domestic Product (GDP) to research and development, and stipulates in its article 23 that the state guarantees the freedom of scientific research while encouraging institutions as a means towards achieving national sovereignty and building a knowledge economy. Few weeks later, the Tunisian constitution was ratified giving similar importance to scientific research and innovation (article 41) ${ }^{\dagger}$. For the first time in both countries, the constitution included explicit clauses that underscore the protection of intellectual property rights and the importance of building a knowledge economy. In this context, only Libya has similar explicit clauses in its constitutions among the other NACs. During the same period, neighboring Arab states reached several important milestones in scientific research (Bizri, 2018e; Malik \& Awadallah, 2013). Both Qatar and Saudi Arabia have seen significant growth in the volume of scientific publications over the previous decade (Bizri, 2018c). The UNESCO Science Report: Towards 2030 (2015) indicated that Saudi Arabia counts two universities among the world's top 500. Some neighboring Arab countries now have several best practices and specific policies for supporting excellence in science and technology (Bizri, 2018c). Hence, there have been various considerable past accomplishments in the field of STI policy in different NAC countries, including measures for technology development and renewable energy incentives (Mansour \& Kanso, 2017; Strielkowski et al., 2016; Melas et al., 2017; Tvaronavičienè et al., 2017; Tvaronavičienè et al., 2018; Tvaronavičienė, 2018; Schiffer, Swan, 2018). However, the evolution of public policies in these areas is limited in literature especially within the political transition period (Bizri, 2018e). Despite major differences in existing science and technology ecosystem settings, many NACs are currently engaged in reform plans that support public science engagement and the development of productive citizens who will advance the national economic interests of establishing knowledge economies. These reforms are driven by a recognition of the huge mismatch between the labor market needs and the outcomes of the education system (Malik \& Awadallah, 2013). With the increasing number of postgraduate students in NACs like Egypt and Tunisia in the past decade (Figure 1), the employment rate remains a top economic challenge (Ayad, 2015; Malik \& Awadallah, 2013). Some might argue that unemployment in NACs increases with higher levels of education, which many education practitioners and planners dispute (Mohamed Ali, 2014). In this respect, it is important to highlight that the root cause is related to the mismatch between the supply and demand for skills in the system, which in turns, reflects the inefficiency of existing measures and policies (Malik \& Awadallah, 2013; Mansour \& Kanso, 2017).

\footnotetext{
${ }^{\dagger}$ Article 41 of Tunisia's Constitution of 2014. https://www.constituteproject.org/constitution/Tunisia_2014.pdf
} 


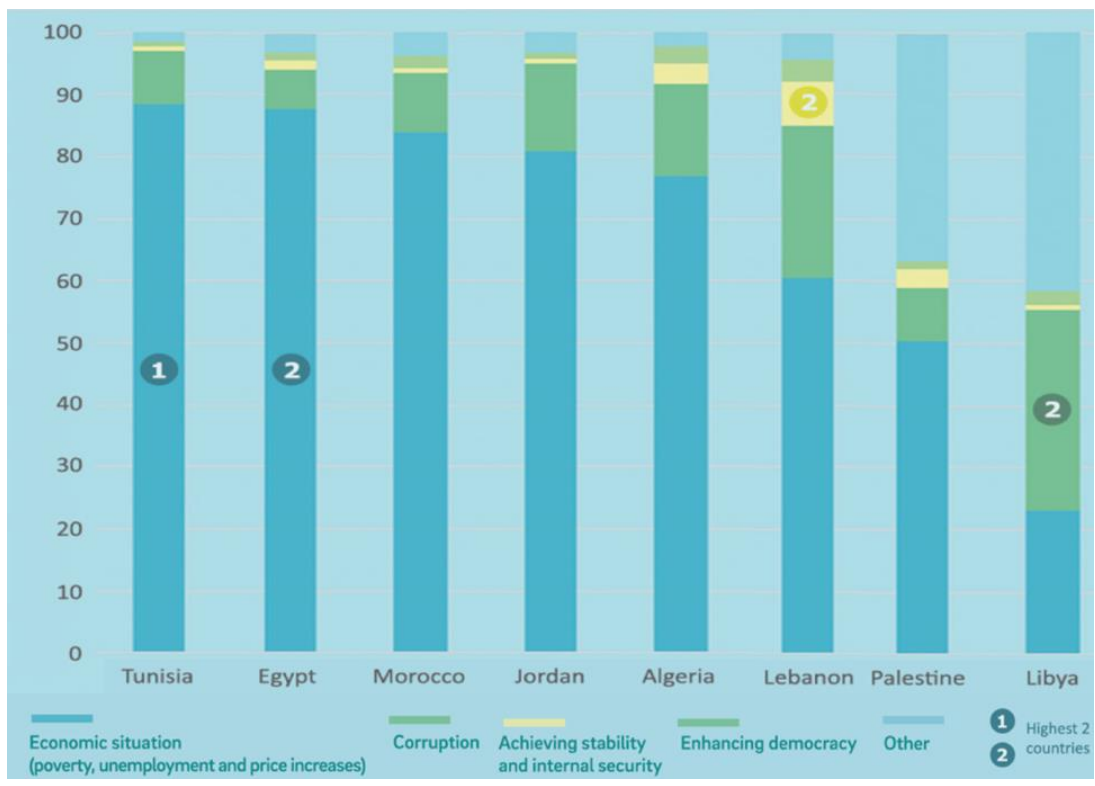

Figure 1. Most important challenges facing North African and South Mediterranean Countries. Source: Derived from Arab Barometer report 2014 and Arab Human Development Report 2016

\section{Innovation ecosystems and governance of science and technology}

The highly-centralized structure of the STI system in NACs might hinder long-term development plans. Despite the existence of overarching bodies, coordination among the main actors of the innovation ecosystem seems insufficient (Hamidi \& Benabdeljalil, 2013; Khodr \& Uherova Hasbani, 2013). In this context, there are striking similarities between NACs. The permanent inter-ministerial committee for scientific research, innovation and technological development in Morocco has a similar role to the Supreme Council of Scientific Research in Egypt where many relevant ministries are represented in one committee that aims to coordinate and align priorities. Both are presided over by the prime minister of each country and considered the principle policy-making body. In Morocco, the government authority for scientific research acts as the secretariat and main supporter for the abovementioned committee. In Egypt, the Ministry of Higher Education and Scientific Research supports the operation of the supreme council, which organized only a few meetings and was disbanded following the Egyptian revolution in 2011 (Bizri, 2018d; Hamidi \& Benabdeljalil, 2013; Radwan \& Sakr, 2017). Like the Moroccan inter-ministerial committee and the Egyptian supreme council, the Jordanian Higher Council for Science and Technology (HCST) plays a significant role with the involvement of several ministers. The HCST has a clearer organizational structure and responsibilities, an independent budget, eight affiliated research centers and specific units dedicated to business incubator network and intellectual property rights (Elshuraydeh, 2007). Furthermore, the coordination of research and innovation activities in Algeria is centrally managed by the Directorate General for Scientific Research and Technology Development (DGSRTD) which was established in 2008. DGSRTD is supported by an inter-sectoral committee composed of representatives from several relevant ministries (Bizri, 2018d).

Although interactions between stakeholders are adequately tackled by several policies in NACs, it still represents a clear challenge with the obvious overlapping between several actors. Most NACs have a complex system of research and innovation that requires strong coordination measures and better allocation of resources(Bizri, 2018b). Fragmentation and lack of coordination are also persistent; for example, the Egyptian Ministry of Higher Education and Scientific Research supervises only 11 research centers while other research centers are supervised 
The International Journal

ENTREPRENEURSHIP AND SUSTAINABILITY ISSUES

ISSN 2345-0282 (online) http://jssidoi.org/jesi/

2018 Volume 6 Number 1 (September)

http://doi.org/10.9770/jesi.2018.6.1(17)

by more than five different ministries. With the idle-status of the supreme council since 2010, this lack of coordination is expected to exacerbate (Radwan \& Sakr, 2017). The case of Lebanon appears to be more decentralized and dynamic compared to the Egyptian governance structure, but several coordination challenges still exist with the involvement of many regulatory and organizational bodies (Khodr \& Uherova Hasbani, 2013). Despite differences in research governance, it remains important for NACs to share best practices and lessons learnt.

Some authors have indicated the ineffectiveness or complete missing of an overarching research strategy in NACs, which widens the gap between policy and implementation (Bizri, 2018e; The UNESCO Science Report: Towards 2030, 2015). A recent study on Egypt's research and innovation ecosystem indicated that strategies and roadmaps developed by relevant national councils are usually not binding to research performing organizations (A. Radwan \& M. Sakr, 2017). Although some coordinating actors are involved in the national system of research and innovation like the Egyptian Academy of Scientific Research, coordination among several actors is not sufficient. Similarly, in Lebanon and Algeria some authors have indicated the importance of having specific coordination measures, supported by policies, that shape and stimulate coordination among several actors at the national level, especially with respect to the role of CNRS in the five-year Science, Technology and Innovation Policy (STIP) in Lebanon (Khodr \& Uherova Hasbani, 2013).

A series of interviews that have been conducted with policy makers in Lebanon in a previous study indicated the insufficient focus on policy-oriented studies, the inapplicability of the existing international studies to the particularity of NACs and the insufficiency of existing recommendations to direct policy at the national level (Khodr \& Uherova Hasbani, 2013). The situation is not significantly different from other NACs where policy planning is not likely to follow an evidence-based approach (Bizri, 2018d).

The governance of science and technology at the national level is often characterized by a centralization approach in NACs (Khodr \& Uherova Hasbani, 2013). A centralized system would benefit from the associated advantages like better interactions between system actors, stricter policy compliance, better allocation of costs and budget planning. Decentralized systems would benefit from the provided "autonomy" which supports scalability and effective development of capabilities and competencies. However, a hybrid system might be more effective in NACs where an inner layer hosts the main driving and central components and the outermost layer includes the regional and sectoral subsystems (Meuer, Rupietta, \& Backes-Gellner, 2015), Table 1.

Table 1. Key Relevant Features of Policies and Strategies for Science, Technology and Innovation in NACs South Mediternean Countries

\begin{tabular}{|c|c|c|c|c|c|c|}
\hline Country & S\&T policy & $\begin{array}{l}\text { Policy-making bodies } \\
\text { with national } \\
\text { authority (councils) }\end{array}$ & $\begin{array}{l}\text { Dedicated } \\
\text { ministry }\end{array}$ & $\begin{array}{l}\text { Main funding } \\
\text { mechanisms }\end{array}$ & $\begin{array}{l}\text { Type of } \\
\text { governance }\end{array}$ & $\begin{array}{l}\text { GERD/GDP } \\
\%\end{array}$ \\
\hline Algeria & $\begin{array}{l}\text { Yes, a national } \\
\text { plan was first } \\
\text { established in } \\
1998\end{array}$ & $\begin{array}{l}\text { - National Academy of } \\
\text { Sciences (planned in } \\
\text { 2015) } \\
\text {-The National } \\
\text { Commission for the } \\
\text { Evaluation of } \\
\text { Permanent Researchers } \\
\text { (since 2000) }\end{array}$ & $\begin{array}{l}\text { Ministry of } \\
\text { Higher Education } \\
\text { and Scientific } \\
\text { Research }\end{array}$ & $\begin{array}{l}\text { National Scientific } \\
\text { Research and } \\
\text { Technological } \\
\text { Development Fund } \\
\text { DGSRTD }\end{array}$ & Centralized & $0.4 *$ \\
\hline Egypt & $\begin{array}{l}\text { Yes, the first } \\
\text { comprehensive } \\
\text { strategy was }\end{array}$ & $\begin{array}{l}\text {-Academy of Scientific } \\
\text { Research and } \\
\text { Technology (since }\end{array}$ & $\begin{array}{l}\text { Ministry of } \\
\text { Higher Education } \\
\text { and Scientific }\end{array}$ & $\begin{array}{l}\text { Science, } \\
\text { Technology, } \\
\text { Development Fund }\end{array}$ & Centralized & 0.72 \\
\hline
\end{tabular}




\begin{tabular}{|c|c|c|c|c|c|c|}
\hline & $\begin{array}{l}\text { established in } \\
2005\end{array}$ & 1972) & Research & $\begin{array}{l}\text { Academy of } \\
\text { Scientific Research } \\
\text { and Technology }\end{array}$ & & \\
\hline Jordan & Yes & $\begin{array}{l}\text {-Higher Council for } \\
\text { Science } \\
\text { andi } \\
\text { (since 1987) }\end{array}$ & & $\begin{array}{l}\text {-Higher Council for } \\
\text { Science } \\
\text { andisepiTechnology } \\
\text {-The Industrial } \\
\text { Scientific Research } \\
\text { and Development } \\
\text { Fund }\end{array}$ & Decentralized & 0.4 \\
\hline Tunisia & $\begin{array}{l}\text { Yes, available } \\
\text { since } 1977\end{array}$ & $\begin{array}{l}\text {-The National Agency } \\
\text { for Scientific Research } \\
\text { Promotion }\end{array}$ & $\begin{array}{l}\text { Ministry of } \\
\text { Higher Education } \\
\text { and Scientific } \\
\text { Research }\end{array}$ & $\begin{array}{l}\text { The National } \\
\text { Agency for } \\
\text { Scientific Research } \\
\text { Promotion }\end{array}$ & Centralized & 0.6 \\
\hline Lebanon & $\begin{array}{l}\text { Yes, available } \\
\text { since } 2006 \\
\text { (STIP) }\end{array}$ & $\begin{array}{l}\text {-National Council for } \\
\text { Scientific Research } \\
\text { (since 1962) } \\
\text {-Lebanese Academy of } \\
\text { Sciences (since 2007) }\end{array}$ & $\begin{array}{l}\text { Ministry of } \\
\text { Education and } \\
\text { Higher Education }\end{array}$ & $\begin{array}{l}\text { National Council for } \\
\text { Scientific Research }\end{array}$ & Decentralized & Unavailable \\
\hline Morocco & $\begin{array}{l}\text { Yes, available } \\
\text { since } 2006 \\
\text { (S\&T vision) }\end{array}$ & $\begin{array}{l}\text {-Hassan II Academy of } \\
\text { Sciences and } \\
\text { Technology since } 2006\end{array}$ & $\begin{array}{l}\text { Ministry of } \\
\text { Higher } \\
\text { Education, } \\
\text { Scientific } \\
\text { Research, and } \\
\text { Training }\end{array}$ & $\begin{array}{l}\text {-Hassan II Academy } \\
\text { of Sciences and } \\
\text { Technology } \\
\text {-InnovAct } \\
\text {-National Agency } \\
\text { for the Promotion of } \\
\text { Small and Medium } \\
\text { Enterprises. }\end{array}$ & Centralized & $0.7 *$ \\
\hline
\end{tabular}

Source: Updated version of (Hanafi \& Arvanitis, 2015), *GERD is based on UNESCO Institute for Statistics (UIS) 2015

Most NACs have supporting specialized policies for renewable energy and the national strategies have listed ambitious targets (Figure 2). Some countries already have an implementation structure in place such as the Renewable Energy and Energy Efficiency Fund in Jordan. This fund does not only provide research and technology grants but also loans and specific mechanisms for small and medium-sized enterprises (SMEs). Jordan was the first country in the region to support a feed-in-tariff scheme for renewable energy. In Egypt, there are five specialized policies to support renewable energy, include funding mechanisms and incentive packages. However, the implementation pathways of these policies are still under discussion (Hadjipanayi et al., 2016), Figure 2.

\begin{tabular}{lll}
\hline Country & Target & Targeted PV capacity (year) [MWp] \\
\hline Jordan & $10 \%$ of the primary energy mix by 2020 & $300(2020)$ \\
Saudi Arabia & $50 \%$ of electricity from non-hydrocarbon resources by 2032 & $17,350(2020 ;$ PV and CSP), 16,000 (2032; PV) \\
Egypt & $20 \%$ of electricity generation by 2020 (of which 12\% wind) & $220(2020), 700(2027)$ \\
Morocco & $42 \%$ of installed power generation capacity by 2020 & $2000(2020 ;$ PV and CSP) \\
Kuwait & $5 \%$ of electricity generation by 2020; 10\% by 2030 & $3500(2030)$ \\
United Arab Emirates & Dubai: 5\% of electricity by 2030 & No specific targets set \\
Israel & Abu Dhabi: 7\% of electricity generation capacity by 2020 & $1750(2020 ;$ PV and CSP) \\
\hline
\end{tabular}

Figure 2. Overall renewable energy future targets and targeted PV capacity for selected MENA countries (Source : (Hadjipanayi et al., 2016)

Specialized food policies in NACs are challenged by the complex national prioritization processes that may be heavily prone to specific political economy considerations (Bizri, 2018a, 2018c). Egypt, Jordan, Morocco and Tunisia have started several attempts to streamline the United Nations' social development goals in their national strategies. In this context, Food and Agriculture Organization of the United Nations has declared in its 2017 "regional overview of food" the importance of developing and implementing joint action plans and strategies for sustainable management of water resources and adapting to the climate change impact on water and agriculture. 


\section{The International Journal}

ENTREPRENEURSHIP AND SUSTAINABILITY ISSUES

ISSN 2345-0282 (online) http://jssidoi.org/jesi/

2018 Volume 6 Number 1 (September)

http://doi.org/10.9770/jesi.2018.6.1(17)

The specialized national strategies on water in NACs are limited while the national policies for supporting the energy-food-water nexus approach are not sufficient. However, a "water" regional initiative is in place. The regional strategy for water security was developed by the Arab Ministerial Water Council in 2009 and resulted in a long-term program (2010-2030), as indicated in the (Arab Strategy for Water Security in the Arab region to meet the challenges and future needs for Sustainable Development 2010-2030, 2012).

\section{Expenditure in research and development}

Despite the existing budgetary pressure, governments remain the main funder of research and development in North African countries. Despite many national strategies in these countries to increase funding contribution by the industry and business sectors, this remains a major challenge (Malik \& Awadallah, 2013). Some measures are already in place for mobilizing resources through public-private partnerships (Bizri, 2018d; Mansour \& Kanso, 2017). However, organizational and regulatory frameworks for these measures are not considered enough to balance and incentivize this partnership while controlling the possible inherent effect from this practice, including possible limitations on open access and data sharing (Rezk, 2016; Radwan \& Sakr, 2017). Public funding of research and development in all NACs are higher than 90\% of Gross Domestic Expenditure on R\&D (GERD) (Radwan \& Sakr, 2017). In this context, France and Italy have been cited in literature as model examples since they have similar GERD percentage value of public funding to North African Countries (Aguiar \& Gagnepain, 2017; The UNESCO Science Report: Towards 2030, 2015). However, the value of industry funding and funding from abroad in these European countries is a major differential factor (Aguiar \& Gagnepain, 2017). This fact suggests that the allocation of a higher percentage of GDP in NACs for research and development should be accompanied by significant interventions to incentivize industry- academia collaboration and encourage private sector contribution in R\&D (Akaev, Korotayev, Issaev, \& Zinkina, 2016; Hamidi \& Benabdeljalil, 2013).

GERD has increased steadily over the past decade in many countries in the region, however, it remains below $1 \%$ for all countries as indicated by the (Global Innovation Index, 2016). In general, GERD is considered low in North African Countries in the past three decades while being lower than the world average (Global Innovation Index, 2016; The UNESCO Science Report: Towards 2030, 2015). Thus, GERD percentage is being considered in this review to reflect only the state interest in science and technology and not in assessing research and innovation potentials or capabilities. Furthermore, the projection of $R \& D$ public funding per sector is not always clear in many NACs with a significant focus on a bottom-up approach. Nevertheless, agriculture, water, biological sciences, energy and medicine have the most focus in the region (Akaev et al., 2016; Bizri, 2018c). This pattern is linked to the relative shift in research policy agendas of these countries towards targeted societal challenges. From another prospective, this can also be further explained by the evident less focus, with respect to the reviewed policies and strategies, on internationally recognized research areas of global interest like big data, synthetic biology, artificial intelligence and smart factories. Moreover, the reviewed strategies and policies did not provide sufficient attention to themes like "citizen science" and "public engagement" in science and technology initiatives and activities (Table 2). Nevertheless, a large research infrastructure is foreseen to be supported in national strategies and is already prioritized (The UNESCO Science Report: Towards 2030, 2015). Furthermore, there is still a primary focus at the institutional levels on research excellence based on the constricted and routine definition in terms of the number of citations of articles published in leading journals (Radwan \& Sakr, 2017). In this respect, some recommendations have been made by several authors to emphasize the relevance of research funding to the existing societal challenges in addition to research communication and exploitation activities, while considering also research excellence based on research citations and bibliometric measures (Amankwah-Amoah, 2016; Elshuraydeh, 2007). Table 2. 
Table 2. Examples of Current National Policies for Science and Technology in North African Countries South Mediternean Countries

\begin{tabular}{|c|c|c|c|c|c|}
\hline & Egypt & Jordan & Morocco & Algeria & Lebanon \\
\hline $\begin{array}{l}\text { Target } \\
\text { percentage of } \\
\text { GERD from } \\
\text { GDP }\end{array}$ & $1 \%$ & $1 \%$ & $\begin{array}{l}1 \% \text { in the short term, } \\
1.5 \% \text { by } 2025 \text { and } \\
2 \% \text { by } 2030\end{array}$ & $1 \%$ & $1 \%$ \\
\hline
\end{tabular}

\section{The evaluation and monitoring component of "science, technology and innovation" policies}

While the lack of pragmatic sectorial policies and action plans could be considered a challenge, the absence of a regulatory component in any national science policy can stifle the scientific and technological process. At present, the evaluation and monitoring system of science and technology in NACs is, in most of the cases, carried out unsystematically by the governmental implementing bodies (Global Innovation Index, 2016; A. Radwan \& M. Sakr, 2017; The UNESCO Science Report: Towards 2030, 2015). Most of the science and technology challenges can be faced by having an independent evaluation and optimization system that pinpoints real-time weaknesses and barriers during the implementation phases and suggests interventions and corrective actions when possible (Marxt \& Brunner, 2013; Weinberg, 2011). Although this system is still missing in many north African countries' science and innovation strategies, it fits well within the many existing structures. Supporting the enforcement of relevant laws and local policies as well as a clear implementation plan of strategies are two integral components for having successful science, technology and innovation policies (A. Radwan \& M. Sakr, 2017). These two components still need further support in the existing national strategies for science and technology. In general, it is widely agreed that having a national strategy without an implementation master plan with alternative pathways and technological roadmaps using clear policy instruments would jeopardize the efficacy and efficiency of the system and delay the local development process (Amankwah-Amoah, 2016; Intarakumnerd, Chairatana, \& Tangchitpiboon, 2002). The Egyptian and Jordanian national strategies for STI is clearly defining ambitious objectives with relevant indicators (Table 3, Table 4). However, it remains important to allocate enough attention to the proper and dynamic evaluation and monitoring dimension (The UNESCO Science Report: Towards 2030, 2015). 
Table 3. Strategic Objectives of Jordan National Science, Technology and Innovation Policy and Strategy (2013-2017)

\begin{tabular}{|c|}
\hline $\begin{array}{c}\text { Encourage the government and the scientific community to adopt the R\&D priorities for developing a knowledge economy identified by } \\
\text { the particular council and the Scientific Research Support Fund in 2010 in Defining Scientific Research Priorities in Jordan for the } \\
\text { Years 2011-2020; }\end{array}$ \\
\hline Generalize a science culture in the education system; \\
\hline Harness R\&D to promote development; \\
\hline Build knowledge networks in science, technology and research; \\
\hline Adopt innovation as a key stimulus for investment opportunities; \\
\hline Translate the results of R\&D into commercial ventures; and contribute to excellence in training and skills acquisition. \\
\hline
\end{tabular}

Table 4. Strategic Objectives of Egypt National Science, Technology and Innovation Policy and Strategy 2017

\begin{tabular}{|l|}
\hline 1. Creating and stimulating a supportive environment for research, scientific production and innovation; \\
\hline 1.1 Enhance the governance of research and innovation and develop specific and sectorial science policies \\
\hline 1.2 Further develop the scientific base of Egypt, including infrastructure and human resources \\
\hline 1.3 Give special support to basic and social sciences in addition to research foresight \\
\hline 1.4 Stimulate industry-academia collaboration \\
\hline 1.5 Support science and society fields and enhance international cooperation. \\
\hline $\begin{array}{l}\text { 2. Technology development and transfer in energy, health, food and agriculture, future technologies and Egypt's industrial strategic } \\
\text { focus which include textiles, therapeutics, metallurgy, chemical industry, electronics, information communication technologies and } \\
\text { deepening local manufacturing. }\end{array}$ \\
\hline
\end{tabular}

Several NACs have taken appropriate measures to establish national observatories in the past decade with the aim of monitoring trends and indicators in science and technology. National observatories in Egypt, Jordan, Lebanon, Palestine and Tunisia receive support from the government (ELshuraydeh, 2007; The UNESCO Science Report: Towards 2030, 2015). Lebanon, through the National Council for Scientific Research (CNRS), is actively planning to put in place a Lebanese Science Technology and Innovation Observatory (LORDI). A regional observatory has been planned since 2014 by UNESCO and the Arab League Educational, Cultural and Scientific Organization (ALESCO). This regional observatory aims to support the Arab region in boosting measures for integration in science and technology, and to coordinate activities between national observatories, in addition to allocating a digital hub for information sharing. However, this regional observatory is still under development as indicated by (The UNESCO Science Report: Towards 2030, 2015). Only few countries, including Egypt and Lebanon, have performed national innovation surveys following Organization for Economic Co-operation and Development (OECD) methodological definition. The innovation survey became an integral part of the operation of Egypt's National Observatory of Science and Technology.

Meanwhile, thematic observatories of science and technology started to spread during the past decade in the South Mediterranean countries (SMC). The heterogeneity nature of most of these thematic observatories, being established at different levels and scales, might hinder the integration and sustainability approach (ELshuraydeh, 2007; The UNESCO Science Report: Towards 2030, 2015). These observatories are established by either an academic institution, public authority, regional programs, international agencies or as a result of a funded project. The Egyptian Food Observatory issues have been published by the World Food Programme between 2011 and 2013 on a quarterly basis. On the other front, the two observatories in Morocco are funded by EU's French and Spanish academic partners (French National Research Institute for Sustainable Development (IRD), Oceanographic Centre of the Canaries), while UNESCO supports the Arab Water Observatory in Egypt. Many Lebanese thematic observatories were established through EU funded projects (Bamyeh, 2015; Elshuraydeh, 2007). 
The International Journal

ENTREPRENEURSHIP AND SUSTAINABILITY ISSUES

ISSN 2345-0282 (online) http://jssidoi.org/jesi/

2018 Volume 6 Number 1 (September)

http://doi.org/10.9770/jesi.2018.6.1(17)

\section{Challenges and opportunities within the regional dimension of STI policies}

There are several strategies and ideas for policy action and initiatives being published worldwide that focus on the potentiality of the recent growth dynamics in NACs. In NACs, science education, knowledge development and scientific research have been always considered in national development plans (Akaev et al., 2016; Malik \& Awadallah, 2013).

Over the past decade, several NACs have moved from one political regime to another under similar circumstances and multiple driving forces. These changes are often accompanied by evolution of relevant policies in science, technology and innovation (Bizri, 2018e). It has been commonly agreed that effective science policy requires the engagement of relevant stakeholders, including industry, civil societies and research institutions (Akaev et al., 2016; Malik \& Awadallah, 2013). The type of engagement varies among NACs, where some countries focus on stakeholders' engagement in the formulation of science policies and very few others focus on their engagement in the implementation phases.

However, the chances for structural development and transformation have been defied by the emerging political and socioeconomic challenges (Malik \& Awadallah, 2013). Discussions about Arab development problems and perspectives are prevailing in literature and strategic reports. Challenges in the field of science and technology vary among Arab countries and also between South and North Mediterranean countries. Yet, while both regions have been subject to reform pressures, the outcomes of change have been strikingly different (Bizri, 2018d). While science policies are designed, and agreed at the regional and national levels, regional integration is generally considered as an obvious challenge facing NACs (Elshuraydeh, 2007; Malik \& Awadallah, 2013). Effective implementation of strategies is also a clear challenge for North African countries where the lack of effective coordination among different stakeholders is persistent and-strategies are usually not binding to national actors (Radwan \& Sakr, 2017). In this respect, local authorities in Arab countries are facing several obstacles such as boosting collaboration with other stakeholders. The negative aspects of the pivotal role of local authorities are also related to their spatial proximity and the risk of developing nepotism and clientelism (Akaev et al., 2016).

Despite the growing number of universities in the NAC region, the public sector still dominates the scene especially with regard to research institutions. Moreover, the private sector tends to be education-oriented but plays a prominent role in Egypt and Lebanon (Elshuraydeh, 2007; Mansour \& Kanso, 2017). As an exception, Tunis and Morocco have a relatively larger private research sector. In addition, Morocco has the biggest share of private higher education institutions among the NACs (Bizri, 2018d; Mansour \& Kanso, 2017). R\&D priority setting in higher education establishments as well as strengthening collaboration with the industry sector were given marginal consideration in the early 1990's (Kearns, 1992). Sectorial and specialized research centers were established in the region in the 1970s while having the government as the main beneficiary. In this respect, the focus areas were the food, energy, water and health sectors. More recently, the focus has expanded to biotechnologies, microelectronics and nanotechnologies (Bizri, 2018d). During the past two decades, several organizations further evolved to support innovation activities and technology transfer like the Centre for the Development of Renewable Energies (CDER) in Algeria, the Institute of Agricultural Research and Higher Education (IRESA) in Tunisia as well as Nile University and Zewail City for Science and Technology in Egypt. Public-private partnership is sufficiently tackled in relevant policies in all NACs. Few countries, though, have translated these policies into concrete actions and instruments (Bizri, 2018b; Mansour \& Kanso, 2017). As an example, Egypt has dedicated a nationwide financial scheme in 2015 to support public-private clusters with a special focus on textiles, renewable energy, water desalination and management, agri-food and smart factory as well as deepening local manufacturing in the petrochemicals and chemistry industry. The Egyptian-established clusters involve more than 135 companies, 18 local authorities and municipalities, 20 NGOs and 55 public and private research institutions. The Egyptian model has some similarities with the "Morocco Innovation Initiative 
Clusters". So far nine clusters have been established under this initiative in Morocco, including energy efficiency, textiles, food, electronic and mechanics, microelectronics and information technology and communication (Bizri, 2018d; Hamidi \& Benabdeljalil, 2013).

The (Akaev et al., 2016) has identified in its latest edition the lack of acquisition, absorption and use of knowledge as the three main problems that limit human development in NACs. The lack of cooperation between the private sector and universities is still widespread in the NAC region and clearly a barrier to a sustainable innovation system (Elshuraydeh, 2007; Malik \& Awadallah, 2013; Ramadan \& Rezk, 2016).

Changing this requires both interventions at the policy level of the countries and a new strategic approach given that innovation is still largely dominated by major multinational groups(Abdelbary \& Benhin, 2018). Only Lebanon and Algeria have achieved good progress during the past decade in enhancing university-industry collaboration in R\&D (

Figure 2). Jordan has been in a static position since 2014, while countries like Morocco, Tunisia and Egypt have experienced a decrease in such collaboration. It is quite clear that corporate collaboration is one of the weakest points in NACs research capacities (Bizri, 2018c; Amr Radwan \& Mahmoud Sakr, 2017). An average of $0.8 \%$ of total scientific productivity in all NACs was based on corporate collaboration in the last 5 years (Bizri, 2018c; Mohamed Ramadan A.Rezk, 2016). It shows also the insignificance of existing mechanisms in linking industry and academia, and underscores the need for new programs and initiatives to encourage such collaboration (Table 5).

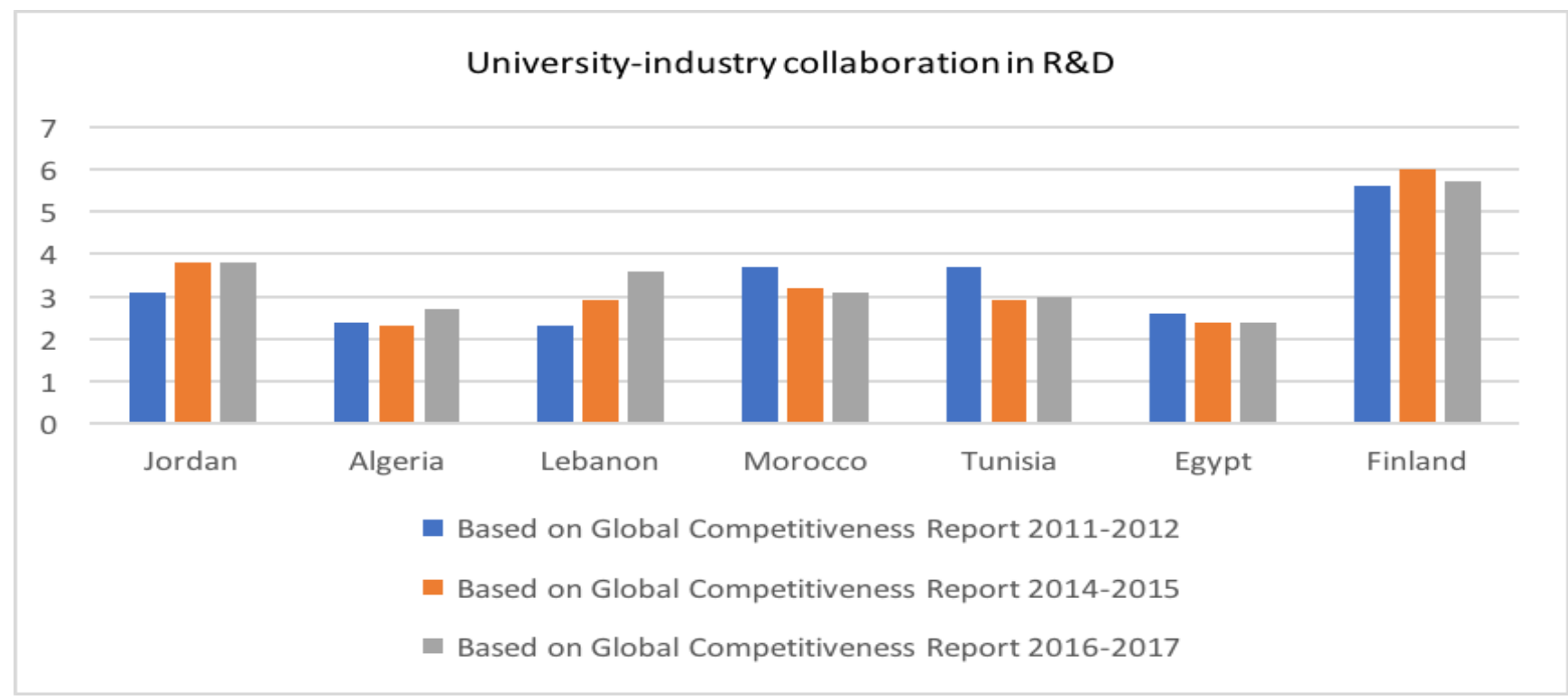

Figure 2. University-industry cooperation in NACs with a comparative highly ranked country. Source: Data derived from Global Competiveness Index 
Table 5. Common STI Policy-related Challenges in NACs that Require Policy Interventions

\section{Common STI policy-related challenges facing NACs}

Gap between policies and implementation in addition to the poor uptake of research evidence by policymakers.

Private funds in research and development are limited due to insufficient incentives and supportive measures.

Lack of institutional focus on research priorities and strategies, especially when aligned with national strategic objectives.

Insufficient overall public funding to meet identified goals.
Source

(Bizri, 2018e; Hanafi \& Arvanitis, 2015)

(Akaev et al., 2016; ELshuraydeh, 2007; Khodr \& Uherova Hasbani, 2013; A. Radwan \& M. Sakr, 2017)

(Bizri, 2018e; Hamidi \&

Benabdeljalil, 2013; Khodr \&

Uherova Hasbani, 2013)

(ELshuraydeh, 2007; Hanafi \&

Arvanitis, 2015)

(Hanafi \& Arvanitis, 2015; A.

Radwan \& M. Sakr, 2017)

(ELshuraydeh, 2007; Mansour \& Kanso, 2017)

(Bizri, 2018e; Hamidi \&

Benabdeljlil, 2015; Mansour \&

Kanso, 2017)

Insufficient networking and clustering of competencies at the national and regional levels.

Limited collaborative activities in research and innovation at the national level.

Insufficient measures to control brain drain.

Data-reliability for evaluation and monitoring of research performance

(Bizri, 2018c; ELshuraydeh, 2007;

A. Radwan \& M. Sakr, 2017)

(Khodr \& Uherova Hasbani, 2013;

A. Radwan \& M. Sakr, 2017)

(Geber, 2013; Gonzalez \&

Chakraborty, 2014; Lucas, 2015)

(Khodr \& Uherova Hasbani, 2013;

A. Radwan \& M. Sakr, 2017)

(Hamidi \& Benabdeljlil, 2015;

Mohamed Ramadan A.Rezk, 2016)

Limited technological absor
informal business sector.

(ELshuraydeh, 2007; A. Radwan \&

M. Sakr, 2017)

Insufficient funding and support to research infrastructure.

An ineffective recruitment policy in academic institutions that doesn't sufficiently retrain talents or recruit highly qualified researchers.

(Abdelbary \& Benhin, 2018;

Elrehail, Emeagwali, Alsaad, \&

Alzghoul, 2018; Hanafi \&

Arvanitis, 2015)

(ELshuraydeh, 2007; A. Radwan \&

M. Sakr, 2017)

(Abdelbary \& Benhin, 2018;

Elrehail et al., 2018) 
The International Journal

ENTREPRENEURSHIP AND SUSTAINABILITY ISSUES

ISSN 2345-0282 (online) http://jssidoi.org/jesi/

2018 Volume 6 Number 1 (September)

http://doi.org/10.9770/jesi.2018.6.1(17)

\section{Discussion and conclusion}

The findings of this review suggest that the existing reforms and development of the STI system in NACs require reorientation towards a higher socioeconomic relevance and innovation focus accompanied by legislative measures, adequate monitoring and evaluation tools as well as effective engagement of relevant stakeholders while leveraging sufficient strategic investments. The highly-centralized structure within the STI system in NACs might hinder long-term development plans. Despite the existence of overarching bodies, coordination among the main actors of the innovation ecosystem seems insufficient. It is also clear that excellence in research and innovation in NACs will not happen without a conducive ecosystem associated with a set of supporting measures in policies-related enforcement actions linked to the relevant R\&D incentives. Linking national strategies with institutional settings is crucial for an effective realization of the desired goals and outputs.

This review indicates also the growing overlapping and less synergistic measures among local actors, including research institutions at the national and regional levels. Bilateral or multilateral research projects among NACs remain extremely rare. Actions to foster specialized and interdisplinary networks need to be more fostered in NACs. The notion of innovation clusters need to be widely promoted and accompanied by sufficient operation mechanisms. In this respect, it is worth mentioning that some NACs, including Egypt and Tunisia, have developed mechanisms to foster technology transfer and public-private partnerships. Nevertheless, these interventions need to be scaled up and further developed to meet the existing gaps. Indeed, inadequate funding for research and development remains a challenge, though not necessary considered the top barrier when compared to ecosystem challenges like research governance and alignment of adequate policies and strategies.

In this respect, it is important to highlight that several stakeholders, including civil societies, should be involved in the development process of policies through focused consultative processes. The responsibility of implementing and monitoring policies should not be assigned to one party, such as a ministry of higher education and scientific research or a higher council for science and technology, as is the case in several NACs. In general, it is widely agreed that having a national strategy without an implementation master plan with alternative pathways and technological roadmaps, using clear policy instruments, would jeopardize the efficacy and efficiency of the system and delay the local development process. The responsibility must be shouldered by planning ministries and inter-ministerial committees led by the highest levels of the political pyramid. These recommendations shall not to be treated as isolated interventions and should be integrated into a joint action plan.

\section{References}

Abdelbary, I., \& Benhin, J. (2018). Governance, Capital and Economic Growth in the Arab Region. The Quarterly Review of Economics and Finance https://doi.org/10.1016/i.qref.2018.04.007

Aguiar, L., \& Gagnepain, P. (2017). European cooperative R\&D and firm performance: Evidence based on funding differences in key actions. International Journal of Industrial Organization, 53 (Supplement C), 1-31. https://doi.org/10.1016/j.ijindorg.2016.12.007

Akaev, A., Korotayev, A., Issaev, L., \& Zinkina, J. (2016). Technological development and protest waves: Arab spring as a trigger of the global phase transition? Technological Forecasting and Social Change. http://dx.doi.org/10.1016/j.techfore.2016.08.009 
Amankwah-Amoah, J. (2016). The evolution of science, technology and innovation policies: A review of the Ghanaian experience. Technological Forecasting and Social Change, 110, 134-142. https://doi.org/10.1016/j.techfore.2015.11.022

Arab Strategy for Water Security in the Arab region to meet the challenges and future needs for Sustainable Development 2010 -2030. (2012). Cairo: Arab Ministerial Water Council Retrieved from http://www.accwam.org/Files/Arab_Strategy_for_Water_Security_in_the_Arab_Region_to_meet_the_Challenges_and_Future_N eeds_for_Sustainable_Development_-_2010-2030.pdf

Ayad, Y. (2015). Egypt 2020 and 2030: Future Vision and Prospective State. The Arab World Geographer, 18(1-2), 39-44. https://doi.org/10.5555/1480-6800.18.1.39

Bamyeh, M. (2015). Social Sciences in the Arab World, Arab Social Science Monitor. Retrieved from http://www.theacss.org/uploads/English-ASSR-2016.pdf

Bizri, O. F. (2018a). Chapter 2 - The Arab Countries' Economies and Development Policies Science, Technology, Innovation, and Development in the Arab Countries (pp. 11-110): Academic Press. https://doi.org/10.1016/B978-0-12-812577-9.00002-7

Bizri, O. F. (2018b). Chapter 3 - Science, Technology, and Innovation Policies and Institutional Landscapes Science, Technology, Innovation, and Development in the Arab Countries (pp. 111-361): Academic Press. https://doi.org/10.1016/B978-0-12-812577$\underline{9.00003-9}$

Bizri, O. F. (2018c). Chapter 4 - Research Output by the Arab Countries Science, Technology, Innovation, and Development in the Arab Countries (pp. 363-453): Academic Press. https://doi.org/10.1016/B978-0-12-812577-9.00004-0

Bizri, O. F. (2018d). Chapter 5 - Innovation and Entrepreneurship in the Arab Countries Science, Technology, Innovation, and Development in the Arab Countries (pp. 455-502): Academic Press. https://doi.org/10.1016/B978-0-12-812577-9.00005-2

Bizri, O. F. (2018e). Chapter 6 - Arab Science, Technology, and Innovation Systems: Challenges, Policy Regimes, and Future Directions Science, Technology, Innovation, and Development in the Arab Countries (pp. 503-569): Academic Press. https://doi.org/10.1016/B978-0-12-812577-9.00006-4

Elrehail, H., Emeagwali, O. L., Alsaad, A., \& Alzghoul, A. (2018). The impact of Transformational and Authentic leadership on innovation in higher education: The contingent role of knowledge sharing. Telematics and Informatics, 35(1), 55-67. https://doi.org/10.1016/j.tele.2017.09.018

Elshuraydeh, K. (2007). Science, Technology and Innovation Profile of Jordan; Evaluation of science, technology and innovation capabilities in the Mediterranean countries. Retrieved from http://www.idaea.csic.es/sites/default/files/Final_report_Jordan_IM_RA.pdf

Geber, H. (2013). Can Mentoring Decrease the Brain drain of Academics from Africa? Procedia - Social and Behavioral Sciences, 93, 215-220. http://dx.doi.org/10.1016/j.sbspro.2013.09.180

Global Innovation Index. (2016). Retrieved from

Gonzalez, J. A., \& Chakraborty, S. (2014). Expatriate knowledge utilization and MNE performance: A multilevel framework. Human Resource Management Review, 24(4), 299-312. http://dx.doi.org/10.1016/j.hrmr.2014.03.001

Hadjipanayi, M., Koumparou, I., Philippou, N., Paraskeva, V., Phinikarides, A., Makrides, G., Georghiou, G. E. (2016). Prospects of photovoltaics in southern European, Mediterranean and Middle East regions. Renewable Energy, 92(Supplement C), 58-74. https://doi.org/10.1016/j.renene.2016.01.096

Hamidi, S., \& Benabdeljalil, N. (2013). National Innovation Systems: The Moroccan Case. Procedia - Social and Behavioral Sciences, 75 , 119-128. https://doi.org/10.1016/j.sbspro.2013.04.014

Hamidi, S., \& Benabdeljlil, N. (2015). Managerial and Technological Innovations: Any Relationship? Procedia - Social and Behavioral Sciences, 181, 286-292. https://doi.org/10.1016/j.sbspro.2015.04.890

Hanafi, S., \& Arvanitis, R. (2015). Knowledge Production in the Arab World: The Impossible Promise (Routledge Advances in Middle East and Islamic Studies) 1st Edition 
Intarakumnerd, P., Chairatana, P.-a., \& Tangchitpiboon, T. (2002). National innovation system in less successful developing countries: the case of Thailand. Research Policy, 31(8), 1445-1457. https://doi.org/10.1016/S0048-7333(02)00074-4

Kearns, K. P. (1992). Innovations in local government: A sociocognitive network approach. Knowledge and Policy, 5(2), $45-67$. https://doi.org/10.1007/BF02692805

Khodr, H., \& Uherova Hasbani, K. (2013). The dynamics of energy policy in Lebanon when research, politics, and policy fail to intersect. Energy Policy, 60(Supplement C), 629-642. https://doi.org/10.1016/i.enpol.2013.05.080

Lucas, R. E. B. (2015). African Migration. Handbook of the Economics of International Migration, 1, 1445-1596. http://dx.doi.org/10.1016/B978-0-444-53768-3.00026-6

Malik, A., \& Awadallah, B. (2013). The Economics of the Arab Spring. World Development, 45, 296-313. http://dx.doi.org/10.1016/j.worlddev.2012.12.015

Mansour, A. M. H., \& Kanso, L. (2017). Science park implementation - A proposal for merging research and industry in developing Arab countries. HBRC Journal. https://doi.org/10.1016/j.hbrcj.2017.06.002

Marxt, C., \& Brunner, C. (2013). Analyzing and improving the national innovation system of highly developed countries — The case of Switzerland. Technological Forecasting and Social Change, 80(6), 1035-1049. https://doi.org/10.1016/j.techfore.2012.07.008

Melas, V.; Lisin, E.; Tvaronavičienè, M.; Peresadko, G.; Radwański, R. 2017. Energy security and economic development: renewables and the integration of energy systems. Journal of Security and Sustainability Issues, 7(1), 133139. https://doi.org/10.9770/jssi.2017.7.1(11)

Meuer, J., Rupietta, C., \& Backes-Gellner, U. (2015). Layers of co-existing innovation systems. Research Policy, 44(4), 888-910. https://doi.org/10.1016/j.respol.2015.01.013

Mohamed Ali, T. (2014). Post-political Transitions in Arab Spring Countries: The Challenges. Procedia - Social and Behavioral Sciences, 109(Supplement C), 250-256. https://doi.org/10.1016/j.sbspro.2013.12.454

Rezk, M. A.; Ibrahim, H. H.; Radwan, A.; Sakr, M. M.; Tvaronavičienė, M.; Piccinetti, L. 2016. Innovation magnitude of manufacturing industry in Egypt with particular focus on SMEs. Entrepreneurship and Sustainability Issues, 3(4), 307318. https://doi.org/10.9770/jesi.2016.3.4(1)

Radwan, A.; Sakr, M. M. 2017. Review of Egypt Science and Technology System: SWOT analysis. Entrepreneurship and Sustainability Issues, 5(2), 204-211. https://doi.org/10.9770/jesi.2017.5.2(3)

Schiffer, A.; Swan, A. 2018. Water security: a summary of key findings exploring islands in Brazil. Journal of Security and Sustainability Issues, 7(4), 855-860. https://doi.org/10.9770/jssi.2018.7.4(20)

Strielkowski, W.; Lisin, E.; Tvaronavičienè, M. 2016. Towards energy security: sustainable development of electrical energy storage. Journal of Security and Sustainability Issues, 6(2), 43-52. http://dx.doi.org/10.9770/jssi.2016.6.2(4)

The UNESCO Science Report: Towards 2030. (2015). Retrieved from http://unesdoc.unesco.org/images/0023/002354/235407e.pdf

Tvaronavičienè, M. 2018. Towards sustainable and secure development: energy efficiency peculiarities in transport sector. Journal of Security and Sustainability Issues, 7(4), 719-725. https://doi.org/10.9770/jssi.2018.7.4(9)

Tvaronavičienė, M.; Nesterova, K.; Kováčik, V. 2017. Energy security and long-term energy efficiency: case of selected counties. Journal of Security and Sustainability Issues, 7(2), 349-357. https://doi.org/10.9770/jssi.2017.7.2(14)

Tvaronavičienè, M.; Tarkhanova, E.; Durglishvili, N. 2018. Sustainable economic growth and innovative development of educational systems. Journal of International Studies, 11(1), 236-244. https://doi.org/10.14254/2071-8330.2018/11-1/19

Weinberg, B. A. (2011). Developing science: Scientific performance and brain drains in the developing world. Journal of Development Economics, 95(1), 95-104. https://doi.org/10.1016/j.jdeveco.2010.05.009 


\section{Acknowledgement}

This work received support from a project 5TOI_4EWAS (Energy, Water and Agriculture in the South Mediterranian Neigbourhood) co-funded by the Horizon 2020 Framework Programme of the European Union under Grant Agreement $n^{\circ}$ 692523
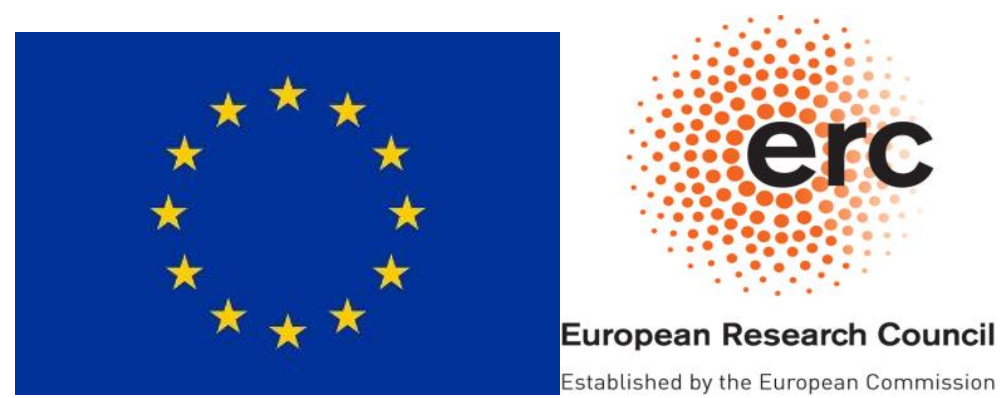

Short biographical note about the contributors

Amr RADWAN is the Head of Research and Innovation Management Department at the Egyptian Academy of Scientific Research \& Technology (ASRT). Amr has a number of published papers and reports in the area of innovation management, research governance, science policy and evidence-based medicine, and co-authored several strategies for S\&T. Before joining the Academy of Scientific Research in Egypt, he was a researcher at Unipharma pharmaceutical corp., where he also founded its process innovation unit. He has a pharmacology background with professional industry experience and has also obtained a Masters of Business Administration (MBA) and a number of diplomas in Intellectual Property Rights and Innovation Management.

ORCID ID: orcid.org/0000-0002-9667-3730

Copyright (C) 2018 by author(s) and VsI Entrepreneurship and Sustainability Center This work is licensed under the Creative Commons Attribution International License (CC BY). http://creativecommons.org/licenses/by/4.0/

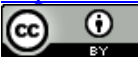

